\title{
PREVALENCE OF ESCHERICHIA COLI F5 (K99) IN PRE-SLAUGHTERED CALVES IN MOSUL CITY
}

\author{
M.G. HASSAN \\ Department of Veterinary Public Health, College of Veterinary Medicine, University of Mosul, Mosul, Iraq. \\ Email: montaha2007montaha@yahoo.com
}

\section{ABSTRACT}

Received at: $25 / 11 / 2013$

The current study was established to determine the prevalence of Escherichia coli F5 (K99) in calves introduced to slaughtering in Mosul city abattoir. Diagnosis

Accepted: 27/2/2014 depend on Sandwich Elisa test (SET) for detection of Escherichia coli antigens. Forty eight fecal samples were collected from calves suffering from diarrhea to detect the presence of pathogenic E.coli F5K99 antigens. The Results revealed 4 $(8.33 \%)$ samples were positive for the presence of E.coli F5 (K99) antigens while $44(91.66 \%)$ samples were negative to these antigens. Therefore we can applied Elisa technique in ante-mortem inspection at abattoir to detect the presence of pathogenic bacteria antigen including E.coli F5 (K99) which may be transmitted through the meat to avoid outbreaks.

Keywords: E.coli F5 (K99), Calves, Mosul city.

\author{
مدى تواجد جراثيم الايشريثيا القولونية F5 في العجول المعدة للجزر في مدينة الموصل \\ منتهى غازي حسن \\ Email: montaha2007montaha@yahoo.com
}

\begin{abstract}
أجريت در اسة مسحية ووبائية لتحديد مدى انتشار جر اثثم الايشريشيا القولونية F5 (K99) من العجول المعدة للجزر في مجزرة مدينة الموصل.

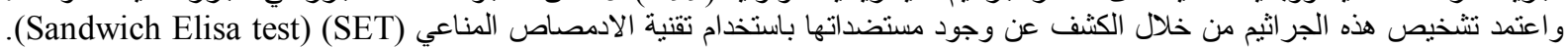

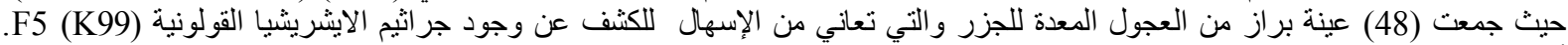

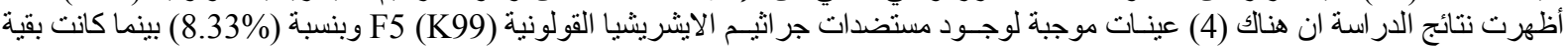

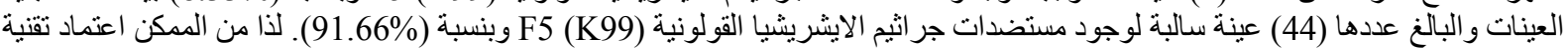

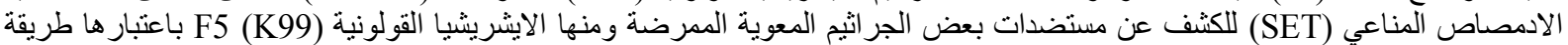

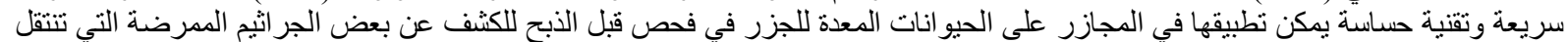

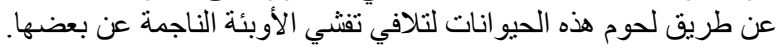

\section{INTRODUCTION}

\section{المقدمة}

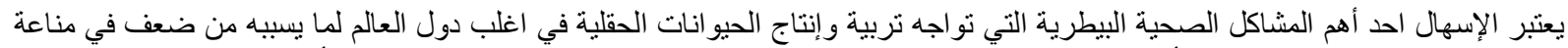

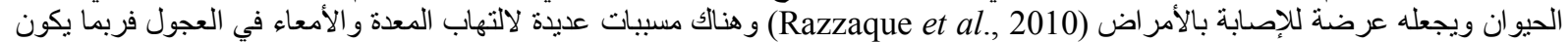

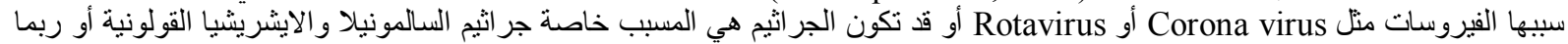

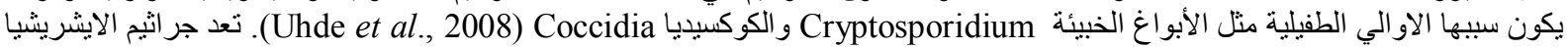

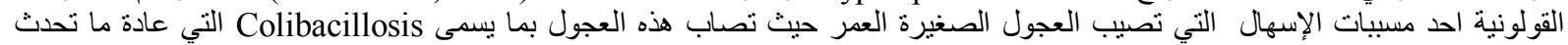

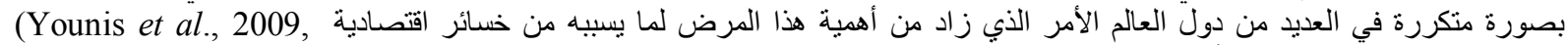

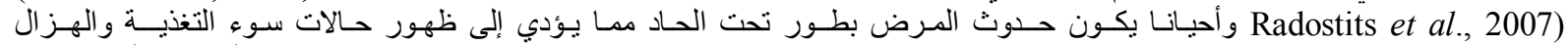

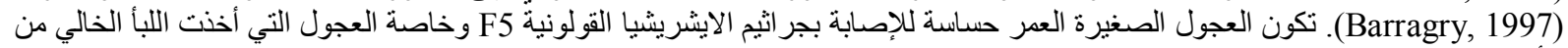

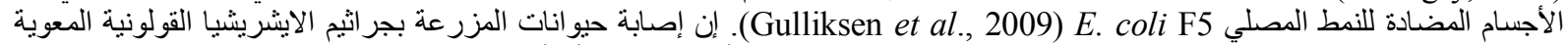

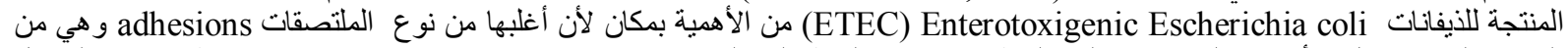

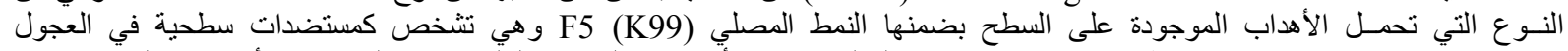
(Rippinger et al., 1995)

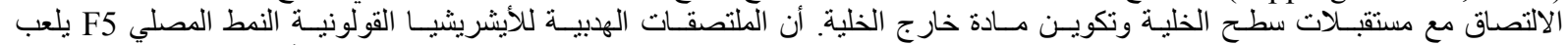

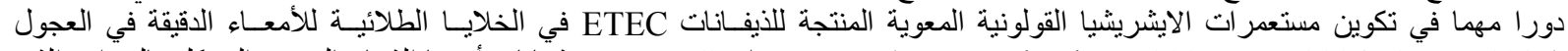

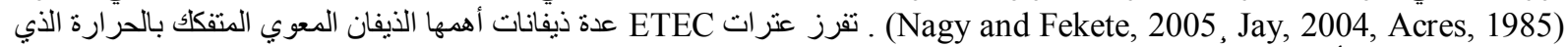

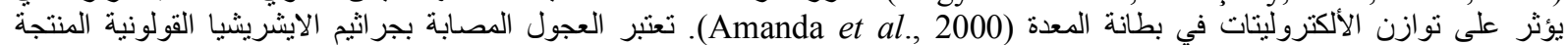

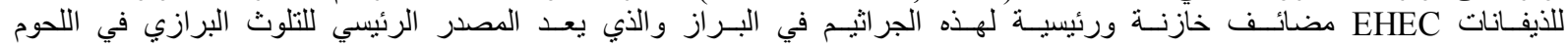




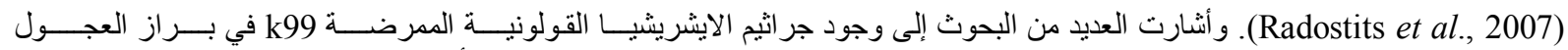

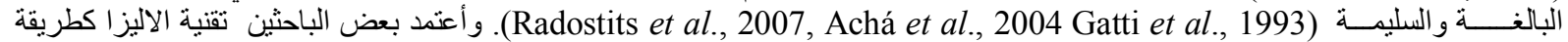

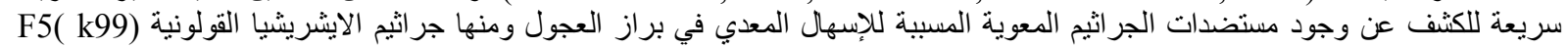

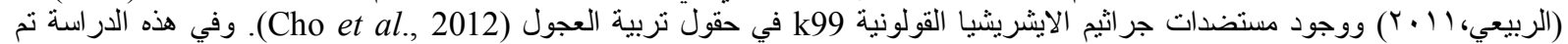
التركيز على الكثف عن مدى انتشار جر اثثم الايشريشيا القولونية النمط المصلي F5 (k99 من العجول المعدة للجزر في مجزرة مدينة الموصل.

\section{MATERIALS and METHODS}

المواد والطرق المعملية

جمع العينات

جمعت (48) عينة براز من العجول المعدة للجزر في مدينة الموصل بعضها كانت تعاني من حالات الإسهال. اخذت عينات البراز من منطقة

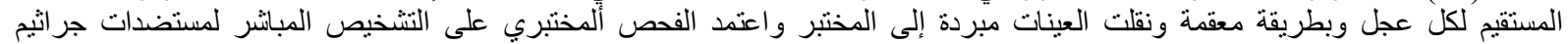

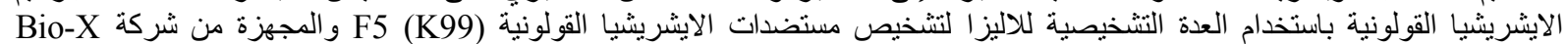

diagnostic

طريقة الاليزا

تم تخفيف محلول الغسل المركز 20X في الماء المقطر ونم تخفيف محلول المنظم المركز 5X في الماء المقطر. تم تخفيف نماذج البراز باستخدام

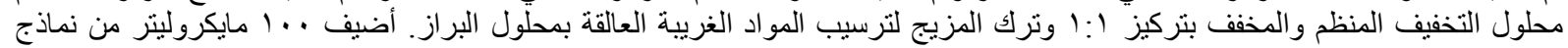

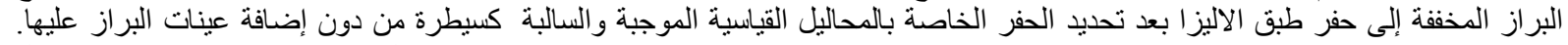

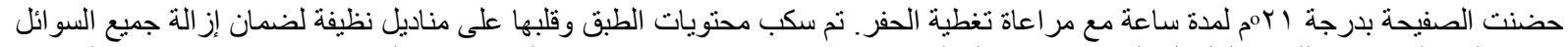

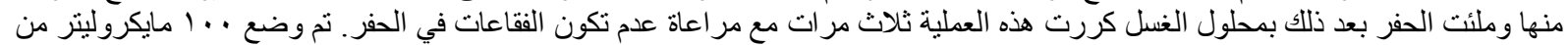

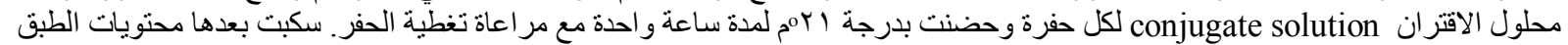

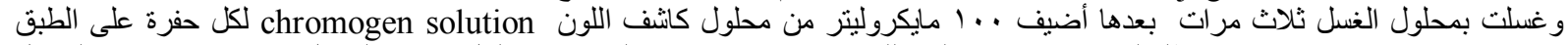

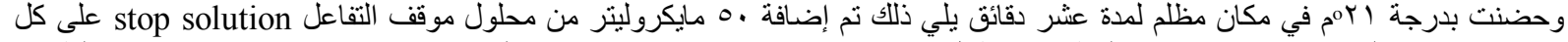

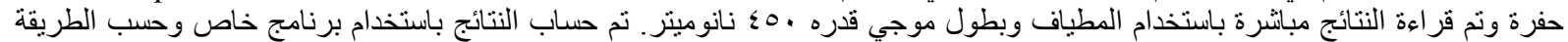

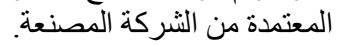

\section{RESULTS}

النتائج

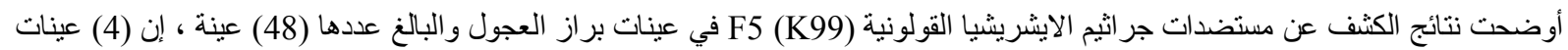

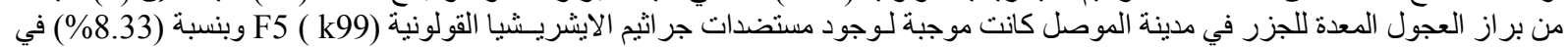

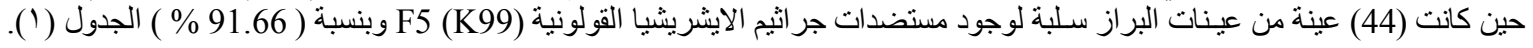

الجدول 1: النسبة المئوية الكلية لوجود مستضدات جر اثيم الايشريشيا القولونية F5 F99 في براز العجول المعدة للجزر.

\begin{tabular}{|c|c|c|c|}
\hline المعدل و الخطأ القياسي & النسبة المئوية & عدد العينات & 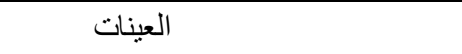 \\
\hline $9.350 \pm \cdot .90 \leqslant$ & 8.33 & 4 & العينات الموجبة لمستضدات E.coli k99 \\
\hline \multirow[t]{2}{*}{$3.329 \pm 0.189$} & 91.66 & 44 & العينات السالبة لمستضدات E.coli k99 \\
\hline & 99.99 & 48 & 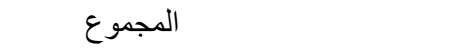 \\
\hline
\end{tabular}

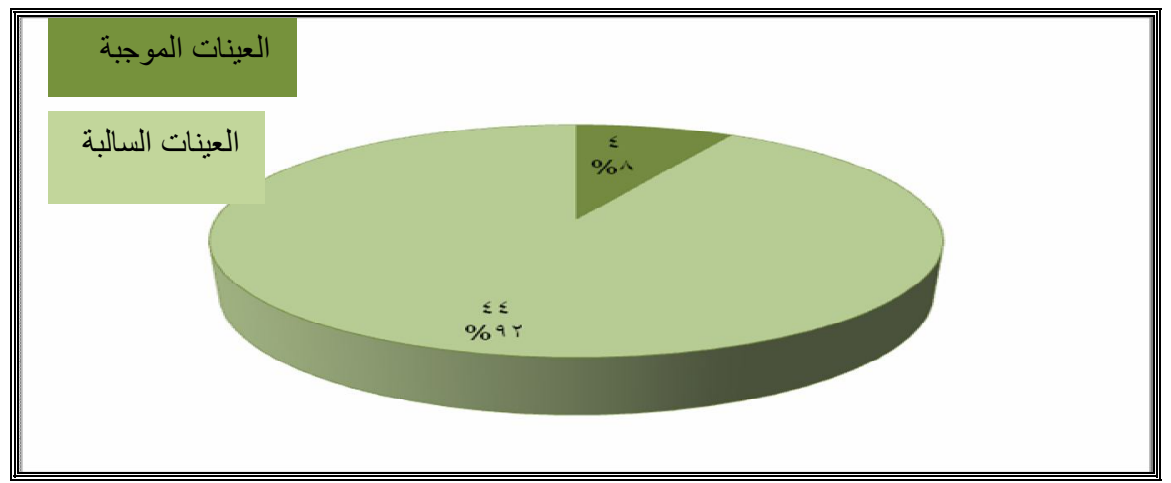

الشكل ا: النسبة المئوية الكلية لوجود مستضدات جر اثثم الايشريشيا القولونية F5 (K99) في براز العجول المعدة للجزر. 


\section{DISCUSSION}

المناقشة

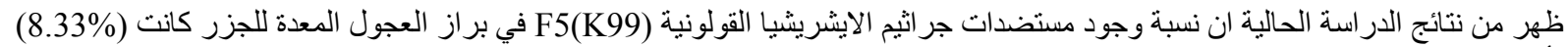

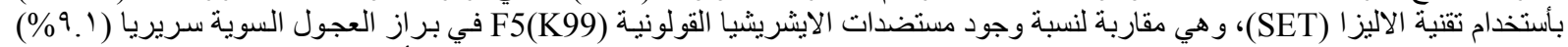

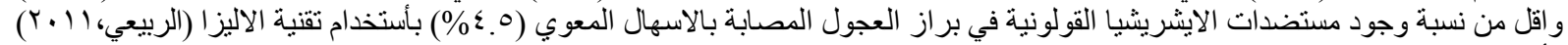

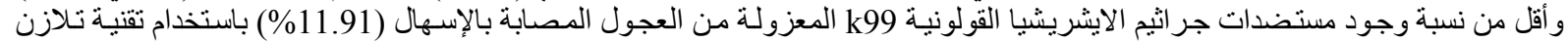

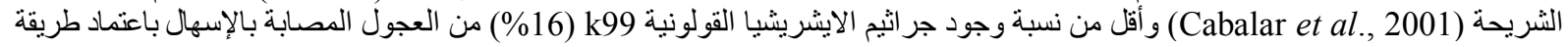
(Achá et al, 2004) biochemical fingerprinting method

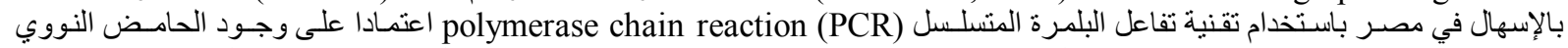

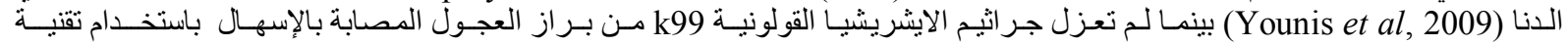

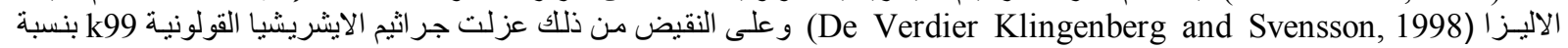

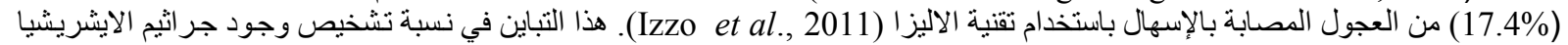

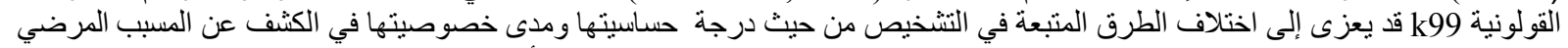

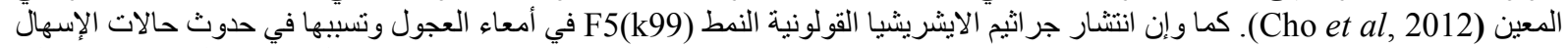

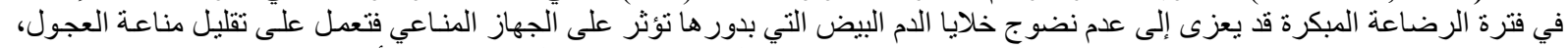

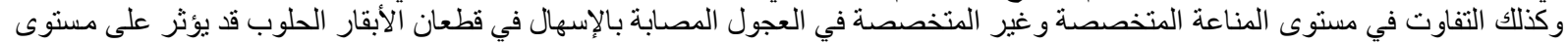

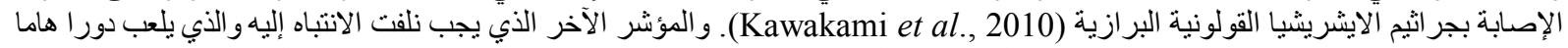

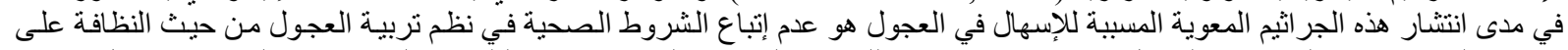

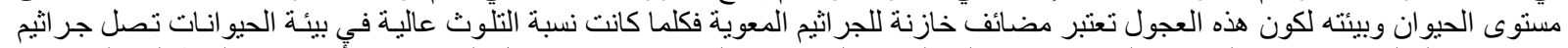

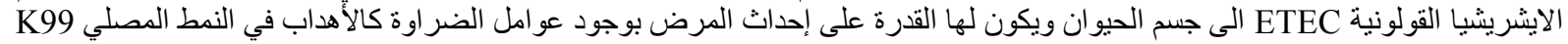

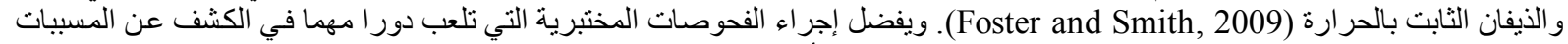

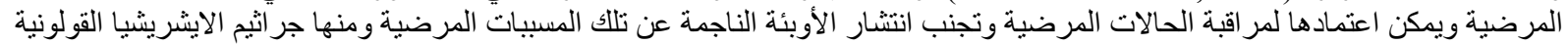
(McGuirk, 2008)

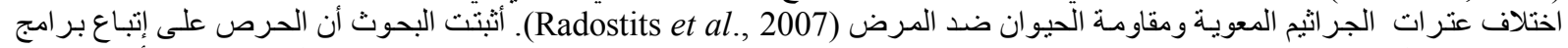

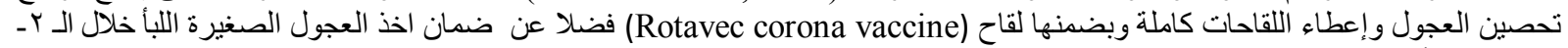

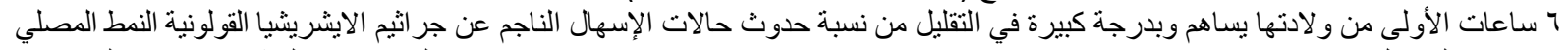

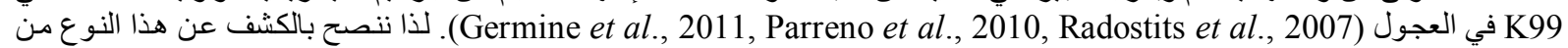

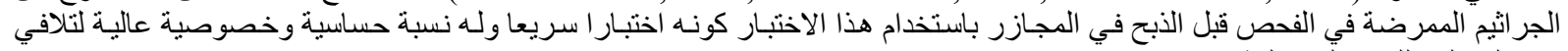
وصولها إلى اللحوم المستنهلكة.

\section{REFERENCES}

$$
\text { المراجع }
$$

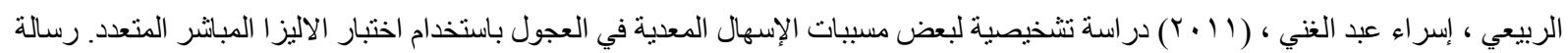

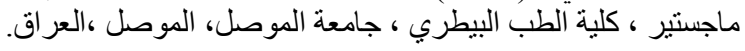

Acha, R.; Kühn, S.J.; Jonsson, I.; Mbazima, P. and Katouli, M and Möllby, G. (2004): Studies on calf diarrhea in Mozambique: Prevalence of bacterial pathogens. Acta. Vet. Scand. 45(1): 27-36.

Acres, S.D. (1985): Enterotoxigenic E. coli infections in newborn calves: a review. Journal of Dairy Science, 68, 229-256.

Amanda, L.; Horstman, M. and Kuehn, J. (2000): Enterotoxigenic Escherichia coli secretes active heat-labile enterotoxin via outer membrane vesicles. J. Biol. Chem. 275 (17): 12489-12496.

Barragry, T. (1997): Calf diarrhoea. Irish Vet. J. 50: 49-58.

Cabalar, M.; Boynukara, B.; Lhan, T. and Ekün, H. (2001): Prevalence of Rotavirus, Escherichia coli K99 and O157:H7 in healthy dairy cattle herds in van, Turkey. Turk. J. Vet. Anim. Sci. 25: 191-196.

Cho, Y.; Sun, D.; Cooper, V.; Dewell, G.; Schwartz K. and Yoon, K. (2012): Evaluation of a commercial rapid test kit for detecting bovine enteric pathogens in feces. J. Vet. Diag. Invest. 24: 559-562.

De Verdier Klingenberg, K. and Svensson, L. (1998): Group A rotavirus as a cause of neonatal calf enteritis in Sweden. Acta. Vet. Scand. 1998; 39(2): 195-199.

Foster, D.M. and Smith, G.W. (2009): Pathophysiology of diarrhea in calves. Vet. Clin. North. Am. Food. Anim. Pract. 25(1): 13-36.

Gatti, M.S.V.; Ferraz, M.M.G.; R.cz, M.L. and de Castro, A.F.P. (1993): Rotavirus excretion in naturally infected pigs with and without diarrhoea. Vet. Microbiol. 37 (1-2): 187-190.

Germine, S.S.; Ebied, M.H.; Ibrahim, F.K.; Mettias, K.N. and Daoud, A.M. (2011): Field evaluation of egg yolk antibodies in prevention and treatment of enteric colibacillosis in calves veterinary serum and vaccine research institute, Abassia, Cairo. Beennhhaa Vet. Med. J. (1): 108-114.

Gulliksen, S.M.; Jor, E.; Lie, K.I.; Hamnes, I.S.; Loken, T.; Akerstedt, J. and Osteras, O. (2009): Enteropathogens and risk factors for diarrhea in Norwegian dairy calves. J. Dairy Sci. 92(10): 5057-5066. 
Izzo, M.M.; Kirkl, P.D.; Mohler, V.L.; Perkins, N.R.; Gunn, A.A. and House, J.K. (2011): Prevalence of major enteric pathogens in Australian dairy calves with diarrhea. Aust. Vet. J. 89(5): 167-73.

Jay, C.M.; Bhaskaran, S.; Rathore, K.S. and Waghela, S.D. (2004): Enterotoxigenic K99+ Escherichia coli attachment to host cell receptors inhibited by recombinant pili protein. Vet. Microbiol. 101(3): 153-160.

Kawakami, S.; Yamada, T.; Nakanishi, N.; Cai, Y. and Ishizaki, H. (2010): Leukocyte phagocytic activity with or without probiotics in Holestein calves. Res. J. Biol. Sci. 5(1): 13-16.

McGuirk, S.M. (2008): Disease management of dairy calves and heifers. Vet. Clin. North Am. Food. Anim. Pract. 24(1): 139-153.

Nagy, B. and Fekete, P.Z. (2005): Enterotoxogenic Escherichia coli in veterinary medicine. Int. J. Med. Microbiol. 295(6-7): 443-454.

Parreno, V.; Marcoppido, G.; Vega, C.; Garaicoechea, L.; Rodriguez, D.; Saif, L. and Fernandez, F. (2010): Milk supplemented with immune colostrums: protection against rotavirus diarrhea and modulatory effect on the systemic and mucosal antibody responses in calves experimentally challenged with bovine rotavirus. J. Immunol. Immunopathol. 136(1-2): 12-27.

Radostits, O.M.; Gay, C.C.; Hinchcliff, K.W. and Constable, P.D. (2007): Veterinary Medicine. $10^{\text {th }}$ ed, W.B. Saunders, England. pp 304-374.

Razzaque, M.A.; AL-Mutawa, T. and Mohammed, S.A. (2010): Diarrhea in pre-weaned calves: Relative risk rates for morbidity and mortality in 13 commercial farm of hot aired zone. Am. J. Anim. And Vet. Sci.5(3): 215-220.

Rippinger P.; Bertschinger, H.U.; Imberechts, H.; Nagy, B.; Sorg, I.; Stamm, M.; Wild, P. and Wittig, W. (1995): Designations F18ab and F18ac for the related fimbrial types F107, 2134P, and 8813 of Escherichia coli isolated from porcine post-weaning diarrhea and oedema disease., Vet. Microbiol. (45): 281-295.

Uhde, F.L.; Kaufmann, T.; Sager, H.; Albini, S.; Zanoni, R.; Schelling, E. and Meylan, M. (2008): Prevalence of four enteropathogens in the faeces of young diarrheic dairy calves in Switzerland.Vet. Rec. 20;163(12): $362-6$.

Younis, E.E.; Ahmed, A.M.; El-Khodery, S.A.; Osman, S.A. and El-Naker, Y.F.I. (2009): Molecular screening and risk factors of enterotoxigenic Escherichia coli and Salmonella spp. in diarrheic neonatal calves in Egypt. Res. Vet. Sci.87(3): 373-9. 